\title{
Contextos interativos no estudo do tema "Origem da Vida" no Ensino Médio sob o olhar de um professor de Biologia
}

Camila Grimes

professora.camilagrimes@gmail.

com

0000-0003-0105-404

Universidade Regional de

Blumenau - FURB - Brasil

Edson Schroeder

ciencia.edson@gmail.com

0000-0001-8917-2017

Universidade Regional de

Blumenau - FURB - Brasil

\author{
RESUMO
}

Os contextos interativos em sala de aula são essenciais para que ocorra a aprendizagem conceitual. Assim, nesta pesquisa temos como objetivo analisar a ótica de um professor de Biologia referente aos contextos interativos vivenciados em um processo de ensino a partir do estudo do tema "Origem da Vida". Participaram da pesquisa 45 estudantes do Ensino Médio, de uma escola pública em Blumenau, Santa Catarina, Brasil. Os dados foram analisados a partir da matriz Histórico-Cultural, pela análise microgenética, proposta por Vygotsky. Como resultados, foi possível perceber que o ensino e a aprendizagem da temática em sala de aula se caracterizam pelas complexidades associadas, visto que aspectos culturais, religiosos e afetivos estão envolvidos na construção dos conceitos científicos, pois, para a construção do conhecimento, os conceitos espontâneos, ou seja, os conhecimentos prévios, servem de base para a internalização dos conceitos científicos.
\end{abstract}

PALAVRAS-CHAVE: Educação Básica. Ensino de Biologia. Origem da Vida. 


\section{INTRODUÇÃO}

A teoria Histórico-Cultural foi proposta e desenvolvida por Vygotsky e seus colaboradores (REGO, 2000). Nessa abordagem teórica, Vygotsky (2001) argumenta que o processo de desenvolvimento do pensamento humano resulta do movimento dialético entre as funções psicológicas elementares (que tem o genoma na sua origem) e as funções psicológicas superiores (que tem a cultura na sua origem). Com base no pensamento vygotskyano as funções psicológicas elementares, como a memória involuntária, o pensamento não verbal e os aspectos mais primitivos da atenção e do desejo estão relacionados às características inatas da espécie humana. Já as inter-relações entre as funções psicológicas superiores, como o discurso intelectual, o pensamento verbal, a atenção voluntária, a memória e os processos volitivos racionais operam sobre o desenvolvimento da consciência.

Para Vygotsky (2001) o desenvolvimento do indivíduo se concretiza do social para o individual, ou seja, das experiências do meio sociocultural dos indivíduos (processo interpsíquico) para o nível individual de cada sujeito (processo intrapsíquico). Discutindo sobre esse entendimento referente aos processos de construção da subjetividade, Oliveira (2002) compreende que a cultura é essencial na constituição do ser humano e por meio dessa, o homem biológico transforma-se em homem sócio-histórico, pois o desenvolvimento psicológico ancora-se nos modos construídos culturalmente em um processo histórico. A cultura não é estática, os indivíduos encontram-se em constante transformação, isto é, um processo dinâmico de recriação do conhecimento. Desse modo, a autora acrescenta que Vygotsky propõe quatro planos históricos: o desenvolvimento da espécie humana (filogênese), a história cultural da sociedade humana (sociogênese), a história individual do ser humano (ontogênese) e as experiências singulares vividas por cada ser humano (microgênese).

Ao encontro desse pensamento, Schroeder (2008) destaca que os indivíduos ao longo da história se constituíram humanos, por meio das relações sociais de produção do conhecimento, relações essas mediadas pela linguagem. A emergência dessas relações se concretiza no que Vygotsky denomina cultura e, nesse sentido, a educação tem importante função na constituição dos sujeitos. Para Vygotsky (2011, p. 864), "a cultura também é produto da vida em sociedade e da atividade social do homem [...]". Cabe dizer que a internalização da cultura e seus instrumentos não se configura como um processo mecânico, mas sim, um processo dinâmico de construção do conhecimento. Nos processos de aprendizagem, o ser humano vai além dos aspectos biológicos da espécie, pois desenvolve capacidades complexas relacionadas às funções psicológicas superiores. Vygotsky (2011, p. 866), assim argumenta, a respeito dessa importante questão:

Agora, o educador começa a compreender que, ao entrar na cultura, a criança não apenas toma algo dela, adquire algo, incute em si algo de fora, mas também a própria cultura reelabora todo o comportamento natural da criança e refaz de modo novo todo o curso do desenvolvimento.

As funções psicológicas dos seres humanos têm sua gênese nas relações do sujeito e seu contexto sociocultural. O desenvolvimento cognitivo humano está relacionado ao desenvolvimento histórico e aos modos sociais da vida dos indivíduos, desse modo a cultura constitui a natureza humana (REGO, 2000). De 
acordo com Vygotsky (1998), as funções psicológicas superiores originam-se nas relações sociais de produção, ao longo do desenvolvimento cognitivo da criança, ao contrário de algo introduzido na criança do exterior para o interior. Para Vygotsky (2001, p.161) "[...] as funções psíquicas superiores têm como traço comum o fato de serem processos mediados, de incorporarem a sua estrutura, [...] o emprego de signos como meio fundamental de orientação e domínio nos processos psíquicos".

Nos processos de ensinar e nos processos de aprender, a mediação do professor e as relações sociais de produção do conhecimento científico são fundamentais para o desenvolvimento dos estudantes. $O$ autor argumenta que o aprendizado está inteiramente relacionado ao desenvolvimento, contudo, os dois são realizados independentemente. Apesar das relações complexas e dinâmicas entre eles, o desenvolvimento dos estudantes não acompanha o aprendizado, pois o desenvolvimento avança mais lentamente e após o processo de aprendizagem. $O$ processo de aprendizagem é mediado pelo professor na Zona de Desenvolvimento Próximo ou Proximal (ZDP) dos estudantes, assim proporciona o desenvolvimento dos mesmos após essa aprendizagem. Nessa direção, Vygotsky (1998, p. 112), descreve um novo conceito referente às dimensões da aprendizagem escolar, o da ZDP:

\footnotetext{
A zona de desenvolvimento proximal é a distância entre o nível de desenvolvimento real, que se costuma determinar através da solução independente de problemas, e o nível de desenvolvimento potencial, determinado através da solução de problemas sob a orientação de um adulto ou em colaboração com companheiros mais capazes.
}

A ideia de ZDP é de grande importância para as investigações na área de formação do estudante e para o plano educacional, pois possibilita a compreensão da dinâmica social/individual que caracteriza o desenvolvimento do indivíduo (VYGOTSKY, 2001). A ZDP possibilita a verificação, além dos ciclos completados, os ciclos que ainda se encontram em desenvolvimento, permitindo assim a caracterização das competências dos estudantes e suas conquistas, bem como a elaboração de estratégias pedagógicas que ajudam nesse processo (REGO, 2000).

Vygotsky compreende que as características tipicamente humanas resultam da interação dialética do ser humano e sua cultura, ou seja, o ser humano transforma o meio para atender suas necessidades e, concomitantemente, se transforma nesse processo (REGO, 2000). Em sala de aula ocorre esse desenvolvimento do ser humano devido aos contextos interativos. Estes consistem nas relações sociais de construção do conhecimento científico estabelecidas entre o professor e os estudantes, bem como entre os próprios estudantes, visando o aprimoramento do pensamento conceitual e da tomada de consciência.

Nos contextos interativos no ambiente escolar ocorre a construção do conhecimento, assim os conceitos novos e em um patamar mais elevado, transformam o significado dos conceitos mais primitivos, dessa maneira quando um novo conceito - conceito científico, é internalizado no pensamento de um estudante, se expande para os conceitos mais elementares - conceitos espontâneos, ao mesmo tempo em que se inserem no pensamento intelectual mais elevado (VYGOTSKY, 1998). Segundo Schroeder (2008), o ensino de Ciências 
Naturais tem importante contribuição na transformação dos conceitos espontâneos, ou seja, conceitos construídos de forma não-consciente, a partir das relações cotidianas, fora do contexto escolar.

Desse modo, destacamos nossa pesquisa que teve como área de abrangência o ensino e aprendizagem de Biologia em sala de aula, com enfoque nos processos de construção de conceitos científico pelos estudantes. $O$ cenário de investigação foi uma classe da primeira série do Ensino Médio e seu professor de Biologia, no desenvolvimento do tema "Origem da Vida".

Investigações apontam uma problemática no ensino e na aprendizagem do tema "Origem da Vida", assim como, forte influência da religião sobre a temática, na visão de estudantes e professores (NICOLINI, 2006; SANTOS, 2007; CERQUEIRA, 2009). Apesar da complexidade de seu ensino, de acordo com as Orientações Curriculares para o Ensino Médio, a origem e evolução da vida é um tema de grande importância no ensino de Biologia, pois os conceitos abordados nessa temática norteiam e orientam todos os outros conhecimentos de Biologia. Desse modo, o ensino dessa temática merece grande atenção, por meio das reflexões, investigações e processos formativos (BRASIL, 2006).

Diante do exposto, estabelecemos como objetivo, analisar a ótica de um professor de Biologia referente aos contextos interativos vivenciados em um processo de ensinar e de aprender, em uma escola pública no Ensino Médio, a partir do estudo do tema "Origem da Vida".

\section{MÉTODO}

Os sujeitos da investigação são 45 estudantes adolescentes de uma turma da primeira série do Ensino Médio no turno noturno e seu professor de Biologia. 0 cenário é uma escola pública da Rede Estadual de Ensino de Blumenau, Santa Catarina, Brasil, no desenvolvimento do tema "Origem da Vida". A escolha do professor responsável pelo processo de ensino investigado aconteceu em função de alguns critérios, tais como: possuir graduação em Ciências Biológicas, ser efetivo no quadro do magistério do Estado de Santa Catarina, ter no mínimo cinco anos de experiência na profissão docente, lecionar para o primeiro ano do Ensino Médio em Blumenau, mostrar disponibilidade, interesse na participação e no desenvolvimento da pesquisa.

O professor possui como formação acadêmica graduação em Ciências Biológicas, especialização em Interdisciplinaridade e em Práticas Pedagógicas Interdisciplinares, além de mestrado profissionalizante em Ensino de Ciências Naturais e Matemática.

Como instrumento para a coleta de dados utilizamos: vídeogravação das aulas, entrevista semiestruturada com o professor e produções escolares. A videogravação e a atividade de transcrição detalhada estão associadas aos estudos socioculturais, com base na teoria Histórico-Cultural (GÓES, 2000a). Desse modo, filmamos todas as aulas referente à temática "Origem da Vida", sendo que, posteriormente, os vídeos foram transcritos. Antes dos estudantes levarem o Termo de Consentimento Livre e Esclarecido para os pais, deixamos claro que as aulas seriam gravadas e que esse material não seria divulgado; somente alguns diálogos seriam divulgados textualmente. Filmamos uma aula antes do início do estudo, com o objetivo de diminuir a curiosidade dos 
estudantes, bem como a inibição, ambientá-los com a câmera e um membro da equipe de pesquisa. Contudo, pelo que podemos perceber em todo o período da investigação, parece que, em nenhum momento, a câmera tirou a atenção dos estudantes das aulas. No entanto, quanto à inibição dos estudantes perante a videogravação não podemos mensurar. O membro da equipe de pesquisa permanecia com a câmera na mão para facilitar o deslocamento entre os grupos e focalizar os estudantes quando falavam, para posterior identificação dos diálogos. 0 processo de ensino investigado durou quase dois meses, tendo início no dia 27 de fevereiro e término no dia 16 de abril de 2012, no total de 8 aulas, de 2 horas/aula cada, isto é, 16 horas/aula observadas. Todas as relações sociais de produção captadas em vídeo e consideradas significativas nesse processo de construção do conhecimento foram transcritas durante a análise.

A entrevista com o professor teve como eixos norteadores: formação, ensino, aprendizagem, sala de aula, a classe, o professor, o processo de ensino e o tema origem da vida. A entrevista facilitou a coleta de dados do processo de construção conceitual e dos contextos interativos, visto que foi realizada após o término das aulas sobre a temática pesquisada. Segundo Bauer e Gaskell (2008), a entrevista semiestruturada individual é uma metodologia de coleta de dados, utilizada de forma recorrente em investigações qualitativas uma vez que fornece dados para a compreensão das relações entre os atores sociais e a sua situação, ou seja, objetiva a compreensão minuciosa das crenças, atitudes, valores, entre outros, relacionados a comportamentos dos indivíduos, em determinados contextos sociais.

Durante as aulas, os estudantes produziram algumas atividades, desse modo, as produções escolares foram outro instrumento para a coleta de dados, como o Relatório de elaboração individual, sobre as hipóteses e o processo de ensino referente à origem da vida. Bogdan e Biklen (1994) sugerem que embora os materiais produzidos pelos sujeitos não sejam muito utilizados, podem servir como fontes de informações de como as pessoas que produziram pensam o mundo. Desta forma, utilizamos as produções escolares, pois, muitas vezes, apresentam aspectos significativos não percebidos em outros instrumentos.

No processo de ensino, procuramos compreender a dinâmica do ambiente histórico e cultural, assim como a mediação do professor no processo de desenvolvimento cognitivo dos estudantes. Para Wertsch (1998), a investigação sociocultural tem como objetivo compreender a mente humana e a sua relação com o contexto, ou seja, a relação entre o indivíduo e a sociedade. Na presente investigação optamos pela análise microgenética como abordagem metodológica. De acordo com Góes (2000a), a análise microgenética é utilizada nas investigações sobre a constituição dos sujeitos, principalmente nos contextos educativos uma vez que consiste numa forma de construção de dados, focada nos detalhes e no recorte de episódios interativos. A análise microgenética apoiase na matriz Histórico-Cultural e tem como objetivo compreender os sujeitos e suas relações intersubjetivas, em contextos históricos e culturais, resultando na compreensão minuciosa dos acontecimentos. Andrade e Smolka (2009) enfatizam, também, que na análise microgenética, Vygotsky propõe o estudo da natureza, da gênese, dos processos biológicos, ontológicos e sociais, suas relações, evoluções e transformações, resultando no desenvolvimento das funções psicológicas superiores, para dessa maneira, compreender o comportamento do ser humano. 
A escola e todos os sujeitos envolvidos na investigação possuem sua identidade preservada e, nesse sentido, atribuímos uma numeração específica para cada estudante, de forma aleatória e referimo-nos ao docente, como Professor. Em todas as produções escolares a escrita original dos estudantes foi mantida. Todos os sujeitos da pesquisa assinaram um termo de consentimento e o projeto de pesquisa foi aprovado pelo Comitê de Ética.

\section{RESULTADOS E DISCUSSÃO}

Os sujeitos dessa investigação, os adolescentes, possuem de acordo com Vygotsky (1998) um desenvolvimento cognitivo diferente se comparado às crianças, uma vez que é na adolescência onde ocorrem os processos de construção do pensamento conceitual. Desse modo, a memória caracteriza-se como uma das primeiras etapas do desenvolvimento psicológico dos estudantes, especialmente na infância, na qual as crianças pensam e automaticamente lembram. Contudo, na adolescência ocorrem transformações no desenvolvimento cognitivo, pois os estudantes lembram e consequentemente pensam. Desse modo, a memória estabelece relações lógicas, proporcionando a transformação dos conceitos concretos em conceitos abstratos.

Os processos de construção de conceitos são extremamente complexos, visto que aspectos individuais e coletivos estão envolvidos. De acordo com a Proposta Curricular do estado de Santa Catarina (2005), os estudos temáticos em sala de aula são fundamentais para que professor e estudante possam estabelecer diálogos e que o professor possa conhecer os adolescentes, seus vínculos sociais, seus projetos e comportamentos. Os adolescentes são constituídos socialmente e culturalmente, além de possuírem uma estrutura de significados simbólicos, bem como apresentam fragilidades no reconhecimento da sua própria cultura, devido à fase de transição na qual se encontram (SANTA CATARINA, 2005).

Entre os 45 estudantes adolescentes, 24 eram do sexo feminino e 21 eram do sexo masculino, com predominância de faixa etária entre 14 e 15 anos. Os adolescentes possuíam características comportamentais e de vestuários extremamente típicos dessa fase, assim como, organizavam-se em sala de aula por grupos de afinidades. Nos momentos em que o Professor não explanava os conhecimentos, os estudantes estavam sempre se relacionando em seus grupos de amizade, contudo, essa prática não afetava o desenvolvimento das aulas. Durante as aulas, os estudantes não participavam muito, até mesmo quando o Professor os questionava, mostrando-se tímidos. Quando questionado sobre as características da classe, o Professor argumentou a respeito da pouca dinamicidade da turma:

\footnotetext{
"No começo do ano eu senti eles desmotivados assim sabe, eles estavam muito quietos e isso me preocupou bastante, então eu não vi uma turma dinâmica, eu já tive turma muito dinâmica que questionava, perguntava, agora essa turma eu vejo como muito quieta, não é uma turma que tem dificuldade, é uma turma muito quieta mesmo, talvez pelo assunto, não sei [...]" (Entrevista professor).
}

As interações em sala de aula são fundamentais para a aprendizagem. De acordo com Garrido (2001, p. 125), a sala de aula é um espaço que permite a 
formação do estudante, pois é o ambiente em que se aprende: "[...] a ressignificar suas concepções, ao ser introduzido no universo dos saberes teoricamente elaborados e nos procedimentos científicos de análise, interpretação e transformação da realidade". Para Schroeder (2008, p. 317), os conceitos científicos possuem uma: "[...] influência significativa na construção da subjetividade quando deixam de ser objetos distantes e estranhos aos estudantes e se transformam em instrumentos do pensamento sobre o mundo objetivo desses estudantes".

Desse modo, na articulação entre pensamento e linguagem, em sala de aula, o professor tem como papel promover uma aprendizagem significativa no desenvolvimento das atividades escolares (VYGOTSKY, 2001). Nesse sentido, Braga (1997) argumenta que as dinâmicas interativas são de extrema importância, visto que nos processos de desenvolvimento humano se relacionam a memória, a imaginação, o pensamento, entre outros, em uma dinâmica rede de significações. De acordo com esse pensamento, no processo de ensino investigado, o Professor procurou criar um conjunto de significações para a aprendizagem dos estudantes, pois possibilitou a articulação entre o pensamento e a linguagem em contextos falados e escritos, concretizados em produção acadêmica individual e coletiva, como textos e cartazes.

Para Vygotsky, a significação conceitual nos contextos educativos é desenvolvida por meio das relações sociais de produção entre professor e estudantes, mediada pela linguagem, sendo este elemento que permite a reflexão e compreensão em nível individual e social dos estudantes, bem como a construção do conhecimento (CACHAPUZ; PRAIA; JORGE, 2004). Nesse sentido, de acordo com Góes (2000b), nas relações sociais a linguagem é fundamental visto que regula as ações e comportamentos tipicamente humanos. A autora aprofunda ainda, uma discussão sobre as relações sociais na perspectiva vygotskyana:

[...] as relações sociais estão na gênese de todas as funções individuais; essas originam-se das formas de vida coletiva, dos acontecimentos reais entre pessoas. Dessa perspectiva, o desenvolvimento é visto como cultural, como um curso de transformações que ocorrem orientadas, antes, para o outro e, então, para si (GÓES, 2000b, p. 120-121).

As relações sociais geram os processos comunicativos nos contextos educativos. Schroeder (2008) analisou as abordagens comunicativas dialogadas e a não dialogadas instituídas entre os sujeitos em seu estudo. Para o autor, na abordagem comunicativa não dialogada, o docente articulava e os estudantes ouviam quase todo o período da aula, prevalecendo, nessa abordagem, a visão científica; na abordagem comunicativa dialogada ocorria a interação comunicativa, por meio de questionamentos e discussões entre professor/estudante e estudante/estudante, além de não deixar a visão científica de lado.

De acordo com esse pensamento, no processo de ensino analisado, isto é, nas relações sociais de produção do conhecimento aconteceram as abordagens comunicativas não dialogadas e dialogadas entre o Professor e os estudantes, e entre os próprios estudantes. Nas abordagens comunicativas a mediação docente no processo de construção dos conceitos científicos é de suma importância, visto que possibilita o desenvolvimento e amadurecimento das funções psicológicas 
superiores dos estudantes. O desenvolvimento desses conceitos acontece na ZPD de cada estudante, pois os conceitos científicos se relacionam com os conceitos espontâneos, transformando-os na sua estrutura, assim podendo-se identificar diversos patamares de conceitos espontâneos e conceitos científicos no mesmo estudante (VYGOTSKY, 2001).

Para Silva, Almeida e Ferreira (2011), conforme a teoria Histórico-Cultural, ao aprender o indivíduo não se encontra sozinho, encontra-se envolvido em processos intersubjetivos constituídos por quem aprende e por quem ensina. No presente estudo, as abordagens comunicativas não dialogadas aconteceram em maior proporção no decorrer das aulas em comparação com as abordagens comunicativas dialogadas. Embora essas abordagens comunicativas tenham ocorrido em menor proporção, foram fundamentais para a construção do conhecimento. Em nossa conversa, o Professor ressalta a importância das relações sociais e da dialogicidade em sala de aula:

\begin{abstract}
"Eu vou dizer que eu percebo quando eles aprendem, quando eu vou explorar algum assunto, quando eu tô falando eles ficam muito atentos ao que eu tô falando, então você percebe quando eles não tão interessados, e é claro que não quer dizer que a sala esteja quieta que eles estão prestando atenção em 100\%, mas você percebe pela interação deles, quando eu jogo um assunto que eu sei que tem a devolutiva, eles debatem comigo, ai eu sei que tem significado pra eles, ai eles estão realmente apreendendo, o aluno ele apreende quando ele faz essas discussões, esses debates, tem que ter interação o tempo todo, o professor tem que perguntar e os alunos quando perguntam, o professor tem que devolver, fazendo eles pensarem, refletirem, isso é importante. Quando eu exploro algum assunto, eu sempre questiono, os alunos trazem o senso comum pra você fazer essa mediação do senso comum com o científico, e choca muito eles, e pra você dizer o que eles aprenderam em casa tá errado, isso é complexo, é complicado" (Entrevista professor).
\end{abstract}

Além de reconhecer o papel das relações sociais em sala de aula, o Professor levanta a problemática dos conhecimentos espontâneos serem carregados de informações culturais e afetivas, dificultando assim a construção dos conhecimentos científicos. Para Eidt e Tuleski (2010, p. 131) "as relações sociais se estruturam, se organizam e se mantêm sobre a base de relações de produção e reprodução das condições materiais da existência". As autoras destacam, ainda, que a intercomunicação com o professor proporciona a transformação do conhecimento, bem como a atividade consciente do estudante, reestruturando seus processos mentais como a atenção, memória, pensamento, comportamento e imaginação. Nessa perspectiva vygotskyana, Schroeder (2008) destaca que as relações entre os grupos sociais são fundamentais para a promoção da aprendizagem, pois com a internalização da cultura por meio da mediação semiótica, o indivíduo transforma suas funções psicológicas superiores, resultando em modificações individuais e também coletivas. Para o autor uma das funções da escola é compartilhar os conhecimentos científicos, construídos historicamente com os estudantes e, desse modo possibilitar reconstruções no plano interpsíquico e posteriormente no plano intrapsíquico.

Como vimos, o Professor reconhece o papel das relações sociais de produção do conhecimento científico e da mediação docente, todavia, as abordagens comunicativas não dialogadas foram predominantes nas aulas referentes à temática em estudo. No processo de ensino e de aprendizagem investigado, os estudantes raramente dialogavam entre si ou questionavam o Professor durante 
a explanação dos conhecimentos pelo mesmo. As abordagens comunicativas dialogadas, no contexto pesquisado, não aconteciam com frequência. $O$ Professor questionou os estudantes em alguns momentos, conforme diálogo apresentado à frente, todavia, possivelmente a timidez foi uma determinante para a falta de interações discursivas. Esse cenário de comunicação não dialogada, na qual o professor ensina e não ocorrem processos interativos dialogados, pode dificultar a construção do conhecimento.

Assim sendo, o Professor não criou contextos, isto é, situações cotidianas na introdução dos conhecimentos científicos, visando os aspectos intelectuais e emocionais. Além disso, considerou pouco os conceitos espontâneos dos estudantes sobre a origem da vida, exceto uma única vez em que desenvolveu um debate sobre a temática e que apresentamos a seguir. Entretanto, antes de abordá-la, trabalhou os conceitos científicos a respeito do método científico e do senso comum, sendo que nesse momento dialogou com os estudantes sobre seus conceitos espontâneos. No debate sobre a origem da vida, limitou a discussão dos estudantes, ou seja, estimulando pouco o contexto interativo em sala de aula.

Nesse momento, apresentamos a descrição da aula filmada, na qual foi desenvolvido um debate entre os estudantes. Nessa aula, o Professor entregou um documento com uma síntese das três hipóteses, Evolução Química, Panspermia e Abiogênese. Solicitou que lessem e, em seguida, fez uma leitura em voz alta e foi explicando cada hipótese. Também citou o Criacionismo, superficialmente. O Professor questionou os estudantes sobre suas opiniões e concepções, bem como algumas vezes tentou o diálogo. Contudo, os estudantes se encontravam retraídos e não falaram sobre o assunto, conforme diálogo a seguir:

\footnotetext{
- "Pessoal sem citar o nome de uma dessas quatro teorias, vocês acreditam em uma dessas quatro? Sim ou não gente?" Os estudantes responderam em coro:

- "Sim". O Professor continuou com os questionamentos:

- "Levanta a mão quem não acredita em nenhuma dessas quatro teorias aqui". Ninguém levantou a mão.

- "Olha só, então a sala toda acredita que uma dessas quatro é tida como verdade, é isso?" Os Estudantes acenaram positivamente e o Professor comentou:

- "Como vocês estão inibidos hoje, eu trouxe um texto com as quatro teorias aqui, vamos fazer uma dinâmica, vocês vão ler individual, uma leitura bem tranquila, depois vamos formar grupos ou duplas né".

- Posteriormente, o Professor solicitou que os estudantes, em equipe, discutissem e apresentassem uma síntese, sobre a opinião do grupo, referente às hipóteses. Depois da discussão nos grupos, o professor argumentou com a classe:

- "Última teoria, a do Criacionismo, então gente, cada uma tem a sua opinião, e religião e futebol em sala de aula não se discute, jamais, os seus conceitos, então sabendo que a ciência não é neutra né, isso é verdade [...]". $\mathrm{E}$ começou a questionar, novamente, agora as opiniões das equipes sobre as hipóteses:

- "Essa equipe ali, se fosse para chegar num consenso sobre uma teoria no grupo vocês conseguiriam?". Alguns agitaram a cabeça negativamente e o Professor questionou:

- "Não? Não quero saber qual é a teoria só quero saber se conseguiram chegar a um consenso ok". E o Professor questionou outro grupo:

- "Aquele grupo de lá, nas discussões de vocês conseguiram chegar a um senso comum, numa aceitação de apenas uma teoria? Nas discussões todos
} 
do grupo são unanimes, não nós acreditamos nessa teoria como verdade, foi isso?". Alguns estudantes agitaram a cabeça positivamente. O Professor continuou com os questionamentos:

- "O outro grupo lá, vocês chegaram num consenso de uma única teoria? Há divergências nas ideias de vocês enquanto teorias? Sim ou não?”. O Estudante 8 respondeu:

- "Não". O Professor questionou outra equipe:

- "E a outra equipe aqui se tivesse que escolher alguma teoria, se tivesse vejam bem... Houve alguma divergência?". O Estudante 34 argumentou:

- "Mais ou menos, houve meio que um desencontro, foi debatido...". O Estudante 33 também falou:

- "Foi debatido...". O Professor comentou sobre o conflito e questionou novamente a equipe:

- "Deu desencontro de opiniões, legal, tudo bem. Então por conta da divergência você achou que o assunto assim oh... se perdeu em contra conhecimento ou você não vamos falar cientificamente falando, ninguém vai ficar com raiva do outro colega, foi isso, foi aquilo, houve essa discussão também ou não?". O Estudante 33 respondeu:

- "Não". Então, continuou os questionamentos com outro grupo:

- "Ok, e esse grupo aqui, se todos tivessem que defender a mesma teoria, vocês conseguiriam chegar em um senso comum? Houve divergência?". O Estudante 30 argumentou:

- "De ideias... Porque como eu falei pra elas cada um tem a sua opinião, as concepções de cada um". O Professor argumentou e questionou:

- "Isso mesmo. Divergências de ideias, concepções, tudo bem. Então gente na fala de vocês, eu não quero saber que teoria vocês acreditam ou deixam de acreditar, isso pra mim não é relevante. A ciência tem as suas teorias $e$ vocês pontuaram uma fala de vocês. Então se eu tivesse que perguntar pra vocês agora, como é que foi no grupo, falar sobre essas teorias. Se tivesse uma palavra chave, foi complexo, foi difícil, foi fácil... quem consegue identificar isso? Falar sobre isso?". O Estudante 13 respondeu:

- "Foi fácil". E o Professor questionou:

- "Por que foi fácil?". O Estudante 13 argumentou novamente:

- "Porque a gente teve a mesma opinião". Depois dessa fala, O Professor encerrou o debate:

- "Teve grupo que com divergências, olha só que interessante... então assim oh, cada um tem as suas concepções, então eu vou passar um filme pra vocês que é a complementação dessas teorias também".

Esse debate configurou-se como uma abordagem comunicativa dialogada, na qual ocorreram relações sociais de produção entre professor/estudante e estudante/estudante. Contudo, esse momento foi único no processo de ensino desta temática, exceto alguns questionamentos esporádicos sobre alguma atividade. Porém, nada relacionado à formação conceitual, visto que na maior parte do tempo nas aulas predominava a abordagem comunicativa não dialogada, na qual o Professor falava e era apoiado pelas imagens projetadas, vídeos e texto para leitura. $O$ debate permitiu as interações discursivas entre os sujeitos de investigação, no entanto o Professor limitou as discussões, ao falar que religião e futebol não se discutem, ou ainda que não queria saber qual teoria os estudantes acreditavam. Ressaltamos que não é função das aulas de Biologia discutir religião, entretanto na perspectiva Histórico-Cultural, para que ocorra a construção dos conceitos científicos em sala de aula, faz-se necessário que o docente dialogue com os estudantes a respeito dos seus conceitos espontâneos para proporcionar a introdução do conhecimento científico, tornando esse significativo para os estudantes. Nesse sentido, de acordo com Vygotsky (2001), o conhecimento do contexto social e cultural dos estudantes pelo docente é fundamental para que ocorra o desenvolvimento das funções psicológicas superiores, pois a aprendizagem dos indivíduos inicia muito antes da 
aprendizagem escolar. Além disso, a aprendizagem escolar se baseia no estágio de desenvolvimento percorrido pelos estudantes, antes do ingresso na escola, seus conceitos espontâneos para a construção dos conceitos científicos. O processo de ensino cria uma ZDP para cada estudante, despertando os processos internos de desenvolvimento por meio das inter-relações com o outro.

Alguns estudantes reconheceram os reduzidos contextos interativos dialogados no processo de ensino, conforme os dizeres do Estudante 44: "Só faltou uma participação maior dos estudantes" (Produção escolar - Relatório. Atividade escrita pelos estudantes). Outros adotaram a postura do Professor, a neutralidade sobre o assunto, segundo o Estudante 18: "[...] E também acho que cada um tem uma opinião sobre as teorias, acho que não tem uma resposta exata para elas" (Produção escolar - Relatório. Atividade escrita pelos estudantes).

O Professor em nossa conversa argumenta que esperava mais questionamentos dos estudantes: "Mas assim, eu até achei que eles fossem questionar mais, mas como é uma turma nova eu não conhecia eles ainda, talvez eles não tinham muita liberdade e eu não fiz nenhuma pesquisa em qual teoria eles acreditavam, isso eu não fiz".

A mediação docente tem um grande papel nos processos de aprender. Nesse sentido, de acordo com Pino Sirgado (2000, p. 66), a apropriação da cultura é um processo no qual o indivíduo adquire significação, formando o ser cultural, desse modo "[...] a significação é a mediadora universal nesse processo e que o portador dessa significação é o outro, lugar simbólico da humanidade histórica".

A pouca utilização de diálogos no processo pode ter sido um problema. Contudo, a temática de estudo possui grande complexidade, visto que a origem da vida, muitas vezes, pode causar dúvidas para o Professor e para os estudantes. Podemos perceber que além da timidez dos estudantes em participar da discussão sobre a origem da vida, o Professor também pode ter receio em promover as discussões em sala de aula a respeito desse tema. Em nossa conversa comentou sobre a dificuldade de ensinar a temática de estudo devido aos aspectos religiosos:

\footnotetext{
"Eu só consigo pensar na religiosa, eu acho que é a mais forte, até mesmo porque eles conheceram uma só até então, a maioria conheceu só aquela, [...] a grande maioria, isso é uma visão que eu tenho agora vão acreditar no Criacionismo, no momento eu percebi isso, que tava muito forte a religião deles ali, eu podia até falar que eu acreditava em outra né, mas eles iriam buscar aquela que eles acreditavam, e eles ficaram muito é... esperando eu falar, que eu falasse qual que era a minha, a teoria que eu acreditava, eu tava vendo que alguém ia perguntar, mas ninguém perguntou, mas eu achei que alguém ia perguntar tá, e aí ia ficar muito difícil eu ter que responder (risos)" (Entrevista professor).
}

Os dogmas religiosos podem dificultar tanto no ensino quanto na aprendizagem do tema "Origem da Vida". O ambiente sociocultural de professores e estudantes, geralmente possibilita contato com o senso comum ou conceitos cotidianos relacionados à temática, além da internalização desse conhecimento pelos indivíduos. Dessa forma, a construção de conceitos sobre a origem da vida nos contextos educativos configura-se como extremamente complexa. 
$\mathrm{Na}$ entrevista, o Professor demonstrou receio que os estudantes questionassem a sua opinião sobre a origem da vida, argumentou que possui certo "medo" que os estudantes percebam na sua fala qual teoria acredita:

"Não, não com medo, eu tinha receio (risos), aí eu pensei como é que eu ia falar naquela né... não eu... acredito só nessa e tá passando as outras também, eu tinha medo dessa devolutiva tá, não houve, mas o momento um dia eu vou encontrar alguém ainda que vai questionar e vai perguntar, qual o professor acredita? [...] eu fiquei imparcial, nenhum momento... fiquei em cima do muro na verdade né, porque assim ninguém me perguntou o que eu era, não sei porque eles não me perguntam, talvez, eu tenho medo na minha fala que eu mostre a teoria que eu acredito né, que as vezes sem querer você acaba se expondo, então assim, eu não falo diretamente, mas os alunos acabam percebendo, ah o professor é de tal teoria" (Entrevista professor).

As explicações não científicas levantadas pelos estudantes devem ser respeitadas pelo docente, visto sua importância sociocultural, bem como trabalhadas em sala de aula como base para a aprendizagem dos conhecimentos científicos. Contudo, cabe ao docente escolher se quer responder ou não os questionamentos relacionados às suas crenças, pois o professor de Biologia não tem o papel de explanar sobre sua fé em sala de aula, mas sim, de disseminar o pensamento científico, visto que o tema "Origem da Vida" encontra-se contemplado em todos os currículos pertinentes ao ensino de Biologia, tais como: Proposta Curricular do Estado de Santa Catarina (SANTA CATARINA, 1998), Parâmetros Curriculares Nacionais para o Ensino Médio (BRASIL, 2000), Orientações Curriculares para o Ensino Médio (BRASIL, 2006).

O Professor abordou as quatro hipóteses da origem da vida no decorrer do processo de ensino, estabelecendo, digamos, um mesmo status no que diz respeito ao potencial explicativo de cada hipótese, não diferenciando as teorias científicas das não científicas. Em nossa conversa, questionamos sobre a sua imparcialidade/neutralidade no ensino das hipóteses da origem da vida:

Pesquisadora: Então uma das estratégias que o professor acredita é ser imparcial?

Professor: "É ser imparcial, mas não diria que é uma estratégia, não o ser imparcial é você ficar indiferente, nas indagações deles, porque você percebe aquela que eles acreditam, entendesse, você percebe... na maioria das vezes você consegue visualizar, e aí assim oh, não é nem você ficar imparcial é você ficar indiferente, porque você não pode dizer assim oh, não eu acho que essa é a certa, eu acredito nessa, mas naquele momento a opinião do professor não é... claro seria válido pra eles ouvir o professor falando, mas o professor não fala, eu percebo que eles percebem aquilo que o professor acredita".

P: Bom eu não percebi isso, eu penso que o professor foi imparcial. O que eu reparei é que na fala do professor não deu para diferenciar o Criacionismo, das outras hipóteses científicas, o professor trabalhou todas no mesmo patamar.

C: "Hum, ah tá".

P: Não diferenciou, e eu acredito que talvez seja por isso que não surgiram os questionamentos, porque o professor colocou as quatro como iguais.

C: "Iguais, não dei ênfase a nenhuma".

$\mathrm{P}$ : Talvez isso tenha feito que eles não questionassem o professor.

C: "Não sei, talvez".

P: Eu não sei qual a visão que o professor tem disso?

C: "Mas você acha que eu deveria dar ênfase em alguma ou não?". 
O mesmo status de potencial explicativo das hipóteses apresentado pelo Professor sobre a origem da vida, pode ter dificultado a construção dos conceitos científicos pelos estudantes. Apesar das dificuldades, especialmente as relacionadas aos aspectos religiosos, compete ao professor ensinar Biologia, ou seja, ensinar sobre as teorias científicas, contudo respeitando as concepções dos estudantes. Cabe ressaltar, ainda nessa perspectiva que em sala de aula o desenvolvimento do indivíduo, bem como o reconhecimento de sua identidade é fundamental para que ocorra a aprendizagem. Nesse sentido, Delizoicov, Angotti e Pernambuco (2002), destacam que o estudante é sujeito de sua aprendizagem, esse é que realiza a ação, construída entre sua relação com os objetos do conhecimento. De acordo com as Orientações Curriculares para o Ensino Médio, o ensino dogmatizado é um grande problema para a formação do cidadão crítico e reflexivo:

\begin{abstract}
Existem dois equívocos igualmente perniciosos que alguns professores chegam a cometer nos momentos em que há contraposição entre valores e conhecimento científico: ou a explicação científica é apresentada como verdade imutável e absoluta, única possibilidade de crença, ou então o conhecimento científico é horizontalmente colocado com todas as demais crenças, configurando-se apenas como mais uma explicação entre tantas. Tais manifestações dogmatizadoras em nada contribuem para o desenvolvimento de uma personalidade crítica, e a isso o professor deve estar muito atento (BRASIL, 2006, p.39).
\end{abstract}

De acordo com Zanon e Freitas (2007, p.101), no ensino de Biologia é importante que os estudantes tomem conhecimento da existência de diversos modelos explicativos de interpretação da natureza, sendo apresentados a eles os modelos científicos e diferenciados dos outros modelos. Dessa forma, os estudantes poderão compreender de forma mais clara, o pensamento científico. Assim, cabe ao docente promover um ambiente de dialogicidade nos contextos educativos e orientar os estudantes a desenvolver análises e argumentações a respeito dos modelos explicativos, para assim transformar e aprofundar os conceitos estudados. Além disso, os autores refletem sobre o ensino voltado para a relação entre ciência e cotidiano, para que os indivíduos possam dar significado aos conceitos aprendidos e compreender o mundo ao seu redor. Nesse sentido, segundo Silva, Almeida e Ferreira (2011), o professor atua na ZDP e tem como função mediar a internalização dos conceitos científicos e da apropriação da cultura, proporcionando assim, a constituição das funções psicológicas superiores, bem como a consciência do próprio pensamento.

A neutralidade/imparcialidade do Professor ao abordar a temática em sala de aula pode estar relacionada a um conflito de ideias (criacionismo versus evolucionismo) que o mesmo possui. Em nosso diálogo expôs:

P: Professor agora vamos conversar sobre cada hipótese, o que o professor pensa sobre o Criacionismo?

C: "Eu vivenciei, eu aprendi essa, essa foi a que eu aprendi, talvez a única que eu aprendi, é a única que eu aprendi e... que a minha mãe acreditava, meu pai acreditava, então você acaba acreditando nessa também, então é a única que eu tive contato foi essa".

P: O professor é Criacionista?

C: "É... em partes, não dá pra dizer $100 \%$ tá, porque tem coisas assim que eu discordo tá, tipo assim, eu não consigo acreditar que existe um Deus que queira mal para as pessoas, se você não fizer vai ser castigado, então essas 
então não dá pra dizer que isso é muito forte, mas não dá pra dizer que eu não acredito entendesse, que existe um criador, então assim, isso pra mim é complexo ainda, eu tenho que trabalhar nisso ainda, então pra mim isso não tá muito claro, entendesse, eu tenho fé, mas é tudo muito particular, da forma que eu acredito, não da forma que é posta pela igreja, não tenho nenhuma religião, não sigo nenhuma religião, eu acho que Deus é uma coisa muito interior da gente, é uma coisa muito pessoal de cada um entendesse, eu não tenho que acreditar que existe uma força superior e tal".

P: O professor falou que a hipótese Criacionista foi a que o professor aprendeu, mas é a que o professor acredita hoje em dia?

C: "Eu diria que... é... eu to muito mais para a questão da Evolução Química enquanto seres vivos né, do que a própria... também não consigo pensar em Adão e Eva que... na história que a bíblia conta, também não acredito nisso, não consigo acreditar, queria acreditar".

$\mathrm{P}$ : Deixa eu tentar entender, o professor tem dúvida quanto a origem?

C: "Isso mesmo".

P: Não sabe ao certo como aconteceu?

C: "É, não sei, se você me perguntar aqui qual, eu não sei, mas muito mais voltado para o Criacionismo".

P: Então com uma tendência para o Criacionismo?

C: "Tendência, porque foi assim que eu aprendi, então assim que eu aprendi, não dá pra negar as origens, e eu tenho um pouco de receio de dizer que não acredito, sabe assim, tá tão impregnado, dá impressão que eu vou falar que eu não acredito e vou ser castigado, eu tenho isso muito forte, porque foi nos passado isso entendesse [...]".

O "medo" do Professor de ser "castigado" é um indicativo das suas crenças, desenvolvidas em seu ambiente cultural e social. Desse modo, inferimos que seus dogmas podem ter propiciado as poucas discussões sobre a origem da vida no processo de ensino. A dificuldade em coletar o conhecimento prévio ou os conceitos espontâneos dos estudantes, bem como problematizar os mesmos, possivelmente, deve-se ao conflito de ideias do Professor. Novamente, evidenciamos que o professor não pode ter receio de discutir ciência com os estudantes, pois segundo Vygotsky (2004), no complexo, dinâmico e dialético processo de educação que gera constantemente embates entre o homem e o mundo, o professor tem um papel ativo de aprimoramento do meio social.

No entanto, compreendemos a posição do docente, pois os conceitos espontâneos, especialmente os relacionados a questões existenciais, estão relacionados às emoções dos seres humanos. A crença religiosa está presente no discurso do Professor devido à aprendizagem do Criacionismo com a sua família, a sua afetividade com a temática, desta forma se torna mais difícil superar esses conceitos espontâneos sobre a origem da vida. Nesse sentido, Vygotsky (2004) argumenta que a partir da reação do organismo a determinado estímulo, a emoção regula e orienta o organismo, organiza internamente o comportamento. Para o autor a emoção está relacionada diretamente com a construção do conhecimento e pode ser determinante na aprendizagem dos conceitos, visto que neste momento estamos analisando o professor como aprendiz: comunicam ao organismo o futuro imediato do seu comportamento e organizam as formas desse comportamento. Daí abre-se para o pedagogo nas emoções um meio sumamente rico de educação dessas ou daquelas reações. Nenhuma forma de comportamento é tão forte quanto aquela ligada a uma emoção. Por isso, se quisermos suscitar no aluno as formas de comportamento de que necessitamos teremos sempre de nos preocupar com que essas reações deixem um vestígio emocional nesse aluno. 
Nenhuma pregação moral educa tanto quanto uma dor viva, um sentimento vivo, e neste sentido, o aparelho das emoções é uma espécie de instrumento especialmente adaptado e delicado através do qual é mais fácil influenciar o comportamento (VYGOTSKY, 2004, p. 143).

Para Vygotsky (2004, p. 143) "as reações emocionais exercem a influência mais substancial sobre todas as formas do nosso comportamento e os momentos do processo educativo". Eidt e Tuleski (2010, p. 141) argumentam que "na medida em que não é possível separar os processos intelectuais e afetivos, é necessário estabelecer um vínculo que leve o aluno a dirigir a atenção ao objeto do conhecimento". Desse modo, o processo pedagógico de ensinar e de aprender motiva quando faz sentido para os estudantes, proporcionando uma melhor compreensão individual e coletiva.

O docente pode ter concepções Criacionistas sobre a origem da vida e defender seus conhecimentos fora do ambiente escolar, todavia nos contextos da educação científica, o docente tem como função apresentar a visão científica. Segundo Vygotsky (2004, p. 454), o professor tem um importante papel na construção do conhecimento científico, uma vez que, para o autor, o verdadeiro mestre é o que "constrói o seu trabalho educativo não com base na educação, mas no conhecimento científico. A ciência é o caminho mais seguro para a assimilação da vida". O autor acrescenta, ainda, que "o desenvolvimento dos conceitos científicos, supera o desenvolvimento dos espontâneos. No campo dos conhecimentos científicos encontramos o nível mais elevado de pensamento que no dos conceitos espontâneos" (VYGOTSKY, 2004, p. 538).

Silva, Almeida e Ferreira (2011) enfatizam que o papel da escola, na perspectiva Histórico-Cultural, é promover experiências e aprendizagens cada vez mais complexas e estimulantes, visando o desenvolvimento dos estudantes. Desse modo, as autoras ressaltam que o professor é o mediador da aprendizagem dos conceitos científicos, assim é de grande importância refletir sobre a constituição da subjetividade do profissional, como ocorre a apropriação das dimensões teóricas e das práticas, bem como ocorre a internalização das práticas pedagógicas. As autoras aprofundam ainda:

Como sujeitos sociais e históricos, os professores têm visões de mundo, valores, sentimentos, comportamentos e hábitos próprios, derivados de um conjunto de experiências vivenciadas em espaços sociais diversos. Assim, estudos sobre as relações do professorado com a cultura são relevantes, por permitirem compreender dimensões da vida social que determinam, em parte, suas práticas pedagógicas (SILVA; ALMEIDA; FERREIRA, 2011, p. 221).

A neutralidade do Professor em mediar a aprendizagem dos conceitos sobre a temática e promover os contextos interativos, pode ter dificultado os processos de construção dos conceitos científicos. Durante a nossa conversa, o mesmo refletiu sobre a sua prática docente e argumentou que pretende reavaliá-la para o próximo ano:

"Eu achei bem complexo tá, a acessibilidade de você poder falar é muito tranquilo, mas você não sabe o que eles estão pensando no momento, eu vi mais dificuldade do que nos anos anteriores, e eu comecei a refletir sobre o tema depois, a pensar né, como que os outros professores estão trabalhando, que relevância estão dando para esse contexto, porque as pessoas tocam muito na religiosidade e esquecem do científico, as vezes, a gente sabe que todo lado tem falha, não é o mérito da questão agora, mas 
foi difícil pra mim, foi bem... eu quero dizer que eu fiquei inseguro naquilo que eu tava passando, não no contexto daquilo que é científico, de tá passando, mas inseguro assim de eu falando com eles e eles me olhando de uma outra forma, do choque cultural e religioso. E eu sempre acreditei que eles não levam pra casa, não sei se alguém levou, penso que não, ah o professor falou que existe outras teorias... [...] Agora eu digo uma coisa, eu tenho uma preocupação o ano que vem, pra trabalhar de novo com os alunos, eu tenho que mudar algumas estratégias assim, vai ser diferente não vai ser mais igual, o ano passado foi de um jeito, esse ano foi de outro e o ano que vem vai ser de uma outra forma, não vou deixar de falar, o planejamento segue com a mesma normativa, mas provavelmente em alguns aspectos vai mudar, ainda mais quando tem alunos que questionam mais né, direcionam mais... puxam mais para outro lado né, então tem isso" (Entrevista professor).

O docente reconhece suas limitações e que precisa mudar alguns aspectos para o próximo ano. A insegurança e a dificuldade relatada no ensino da origem da vida reflete toda a complexidade já discutida sobre os processos educativos da temática. A preocupação do Professor com a reação da família aos conteúdos aprendidos em sala de aula é um desafio a mais, pois essa inquietação pode limitar seu ensino, prevalecendo, dessa forma, os conceitos espontâneos sobre os conceitos científicos. Segundo Vygotsky (2004, p. 452) "para lecionar pode-se saber muito pouco só que com clareza e precisão. Para orientar os próprios conhecimentos do aluno é necessário saber bem mais". De acordo com Praia, Cachapuz e Gil-Pérez (2005), as concepções de ciência que os professores possuem têm implicações sobre o que e a forma como ensinam. Portanto, faz-se necessário que o curso ofereça momentos de reflexão e discussão sobre os conhecimentos referentes à origem da vida, a partir das concepções que os estudantes já têm construído ampliando essas discussões para o seu ensino nas escolas.

Na ciência não existem verdades absolutas e, conforme Nicolini (2006), os conhecimentos científicos sobre o tema "Origem da Vida", na atualidade, não representam um consenso no meio científico, devido às lacunas existentes no pensamento científico sobre a temática. Contudo, a ciência busca, constantemente, respostas pelas evidências e os experimentos. Nesse sentido, Porto e Falcão (2010, p. 14) realizam importante reflexão sobre o conhecimento científico, referente à origem da vida, e sua característica não dogmática:

\footnotetext{
Fundamentados em conhecimentos oriundos da Cosmologia, da Física e da Química, estudos científicos sustentam hipóteses e cenários plausíveis para a origem da vida. Essas hipóteses e cenários, embora contem, em sua elaboração, com dados admitidos como razoáveis, oferecem espaço a controvérsias. Ressalte-se que questionamentos expressam aspectos da natureza do conhecimento científico. Este, por seu caráter intrinsecamente aberto à discussão, não dogmático por definição, sempre dá margem ao surgimento de dados que fortaleçam ou refutem as hipóteses levantadas pelos pesquisadores.
}

Devido a constante transformação do conhecimento científico, segundo Futuyma (1997, p. 340-341), a Evolução Química trata-se da hipótese científica mais aceita atualmente, com o objetivo de compreender os processos que deram origem à vida: 
orgânicas não se fossilizam. A origem da vida é um assunto de especulação teórica e experimento de laboratório [...]. Muitos pesquisadores, começando por Miller e Urey (1953) e Oparin (1953), demonstraram experimentalmente que a síntese de cadeias de macromoléculas aminoácidos, açucares, purinas e pirimidinas - vão se formar em abundância se energia na forma de eletricidade ou luz ultravioleta for descarregada em uma atmosfera reducional (p.ex., de $\mathrm{H} 2, \mathrm{CH} 4, \mathrm{NH} 3$ e $\mathrm{H} 2 \mathrm{O}$ ), como aquela postulada para a Terra pré-biótica. Os aminoácidos irão formar espontaneamente polipeptídeos curtos, mas as condições para a formação espontânea de nucleotídeos e ácidos nucléicos parecem ser consideravelmente menos prováveis. Monômeros podem se tornar concentrados e formar polímeros estáveis pela absorção em partículas minerais, tais como argila, ou por evaporação ou congelamento. Polipeptídeos, além do mais, irão se agregar em gotas coloidais ou coacervados que, alguns já sugeriram, poderiam servir como "protocélulas", dentro das quais poderiam ocorrer o crescimento e a replicação. Esses coacervados podem, na realidade, catalisar uma variedade de reações orgânicas. Na presença de polimerases de RNA, pequenos filamentos de RNA irão se formar a partir de nucleotídeos, mesmo na ausência de RNA pré-existente (Eigen et al. 1981); e moléculas de RNA irão se replicar em um sistema extracelular de modelos de RNA, nucleotídeos livres e polimerases. Além disso, seleção natural e mutação ocorrem em tais complexos; ocorrem erros em cópias e algumas sequências de RNA replicam-se mais rapidamente que outras.

Futuyma (1997) argumenta, também, que apesar de todo esse conhecimento teórico sobre a origem da vida, ainda não foi possível demonstrar novamente, em laboratório, a origem de polipeptídeos codificados de ácido nucléico que possam agir como polimerase do ácido nucléico. Contudo, registros fósseis indicam que a vida possui 3,4 bilhões de anos. Assim, a inabilidade dos cientistas em sintetizar a vida "novamente" em meros 30 anos não é argumento contra a hipótese sobre a origem da vida mais aceita pela ciência na atualidade.

Apesar de não haver um consenso científico sobre a origem da vida no planeta Terra, existe uma hipótese mais aceita. No entanto, Nicolini (2006) defende que há um abismo entre o que é discutido na academia e o que deve ser debatido na sala de aula, a respeito do tema "Origem da Vida". Porto e Falcão (2010) salientam que é de grande importância a investigação das explicações científicas sobre a origem da vida no Ensino Médio, da motivação de aprender a temática e da permanência dos conceitos espontâneos dos estudantes, ou seja, suas crenças religiosas, após a aprendizagem dos conhecimentos científicos, para a compreensão dos processos de construção do conhecimento no ambiente escolar.

Nicolini (2006) ressalta que a ciência não é imutável, hipóteses são levantadas continuamente e a ausência de um ensino de qualidade sobre o tema "Origem da Vida", na formação do licenciando de Ciências Biológicas, pode trazer consequências sobre o seu ensino. De acordo com Grimes e Schroeder (2013), existe uma necessidade de discussões mais aprofundadas sobre o tema nos cursos de Ciências Biológicas no que diz respeito às questões conceituais, sobretudo, às relacionadas ao seu ensino nas escolas, uma vez que o tema "Origem da Vida" faz parte dos conteúdos da educação básica. Desse modo, segundo Santos (2007) é de grande importância, a inserção da sociologia, filosofia e história da ciência nos cursos de licenciatura, desse modo contribuiria para a reflexão do futuro profissional. Nessa perspectiva, Carvalho (2005) reflete que o ensino de Ciências Naturais necessita de uma renovação epistemológica dos 
professores, com discussões e tomadas de consciência, bem como, uma renovação didática e metodológica de suas aulas para que os estudantes percebam a coerência entre o falar e o fazer.

Segundo a Proposta Curricular de Santa Catarina - Temas Multidisciplinares (2005) cabe à educação escolar possibilitar o pensamento científico, pois o pensamento dogmático acrescenta pouco ao desenvolvimento intelectual dos estudantes, uma vez que os conhecimentos científicos estão em constante transformação, são legitimados por meio do método científico e permitem uma compreensão de mundo mais profunda e complexa. Assim a capacidade de pensar promove a autonomia dos estudantes na compreensão do conhecimento, na elaboração de novos conhecimentos, tendo como ponto de partida os conhecimentos já internalizados (SANTA CATARINA, 1998). Contudo, conforme Costa, Melo e Teixeira (2011, p. 125) "o papel do educador não é o de impor um conhecimento, e sim o de apresentar, ao aluno, novas formas de ver, de explicar e de se relacionar com o mundo". Os autores acrescentam ainda, que o ensino deve ser focado no desenvolvimento do cidadão consciente, capaz de argumentação e escolha, assim como tenha a compreensão de todas as formas de conhecimento.

Para Vygotsky (2004, p. 64), "o processo de educação deve basear-se na atividade pessoal do aluno, e toda a arte do educador deve consistir apenas em orientar e regular essa atividade". O autor ressalta que o meio social dos estudantes, as suas experiências cotidianas é o grande estímulo para o processo educacional. Assim cabe ao professor organizar o meio, pois o papel da educação está diretamente relacionado à realidade dos sujeitos, seu papel é educar para a vida, "[...] o nosso objetivo final não é inocular méritos escolares especiais seja de que espécie for, mas comunicar habilidades e hábitos para a vida, que a iniciação a vida é o nosso objetivo final" (VYGOTSKY, 2004, p. 68).

Desse modo, argumentamos que nessa educação para a vida as interações discursivas são fundamentais, pois a mediação docente na ZDP dos estudantes, a cooperação entre os estudantes em sala de aula, possibilitando o desenvolvimento das relações sociais de produção do conhecimento, desencadeiam o desenvolvimento do pensamento conceitual. Apesar da complexidade da temática de estudo, sua ligação com a emoção e a afetividade, o professor tem como função explorar os conceitos espontâneos dos estudantes com vistas à construção dos conceitos científicos, independente de seus próprios conceitos espontâneos.

\section{CONSIDERAÇÕES FINAIS}

As interações discursivas são fundamentais nas aulas de Biologia, pois permitem a compreensão dos estudantes sobre os significados da ciência, além das mudanças que estes significados sofrem no decorrer das suas trajetórias acadêmicas.

No processo de ensino, o Professor tem função fundamental na organização do ambiente de aprendizagem, no desenvolvimento das interações discursivas em sala de aula, na proposição de tarefas desafiantes e significativas aos estudantes, bem como a efetivação de processos que poderão gerar aprendizagem e o desenvolvimento dos seus estudantes ao aprenderem os 
conhecimentos científicos. Assim, o docente atua como mediador com vistas à internalização dos conhecimentos científicos e no desenvolvimento das funções psicológicas superiores, visando a tomada de consciência dos indivíduos.

$\mathrm{Na}$ aprendizagem de conceitos científicos que podem gerar ideias conflituosas, os temas controversos, a construção do pensamento conceitual se torna ainda mais complexa, pois apesar da abordagem pedagógica do professor, o estudante de forma consciente pode não construir os conceitos científicos. Neste sentido, muitos conhecimentos da Biologia podem gerar conflitos éticos, morais e culturais, na sua aprendizagem. Desse modo, para o ensino desses conteúdos necessita-se dedicação maior e preparo docente.

Neste estudo, o Professor abordou os conceitos científicos sobre a temática em sala de aula, contudo, expôs a hipótese com elementos não científicos no mesmo patamar de potencial explicativo que as hipóteses científicas. Além disso, promoveu poucas interações discursivas nas aulas de Biologia, não coletando os conceitos espontâneos dos estudantes e questionando pouco os estudantes durante o processo de ensino.

Em sala de aula, o docente não explicitou as suas crenças, contudo, na entrevista estas ficam claras. Compreendemos, que além de outros aspectos, como os afetivos e culturais dos estudantes, possivelmente, as ideias conflituosas do professor de Biologia possam ter influenciado na construção dos conceitos científicos sobre a temática de estudo. Ressaltamos que o professor tem como papel promover o desenvolvimento do pensamento conceitual e introduzir, cada vez mais, os estudantes no pensamento científico mais elaborado, ou seja, mediar o processo de construção dos conceitos científicos nas aulas de Biologia.

Destacamos a necessidade de discussões mais aprofundadas dos conteúdos que geram conflitos no ensino de Biologia, nos cursos de Ciências Biológicas, no que diz respeito às questões conceituais, sobretudo, às relacionadas ao seu ensino nas escolas, uma vez que fazem parte dos programas curriculares da educação básica. Os professores necessitam também de assistência e apoio constantes no desenvolvimento de sua profissão, como cursos de formação continuada. Entretanto, muitas vezes, encontram-se isolados, até mesmo dos seus colegas de profissão. 


\title{
Interactive contexts in the study of the topic "Origin of Life" in High School from the perspective of a Biology teacher.
}

\begin{abstract}
The interactive contexts in the classroom are essential for conceptual learning. In this sense, we present a research with the general purpose of analyzing the optics of a Biology teacher referring to interactive contexts experienced in the learning process of the studied topic "Origin of Life". The participants were 45 high school students from a public school in Blumenau, Santa Catarina, Brazil. The data were analyzed through the Cultural History theoretical frame, and microgenetic analysis, proposed by Vygotsky. As a result, it was revealed that the teaching and learning of the topic in the classroom are characterized by associated complexities, like cultural, religious, existential and emotional involved in the construction of scientific concepts, because, for the construction of knowledge, the spontaneous concepts, that is, prior knowledge, serve as a basis for the internalization of scientific concepts.
\end{abstract}

KEYWORDS: Basic Education. Biology Teaching. Origin of Life. 


\section{REFERÊNCIAS}

ANDRADE, J. de. J. de; SMOLKA, A. L. B. A construção do conhecimento em diferentes perspectivas: contribuições de um diálogo entre Bachelard e Vigotski. Ciência e Educação, v. 15, n. 2, p. 245-268, 2009.

BAUER, M. W.; GASKELL, G. Pesquisa qualitativa com texto, imagem e som: um manual prático. 7. ed. Petrópolis: Vozes, 2008.

BOGDAN, R.; BIKLEN, S. K. Investigação qualitativa em educação: uma introdução a teoria e aos métodos. Porto: Porto Ed., 1994.

BRAGA, E. dos. S. Vídeo, escrita, leituras, recordações: cultura e memória na sala de aula. In: GÓES, M. C. R. de.; SMOLKA, A. L. B. (Org.). A significação nos espaços educacionais: interação social e subjetivação. Campinas: Papirus, p. 87-109, 1997.

BRASIL. Ministério da Educação, Secretaria de Educação Média e Tecnológica. Parâmetros Curriculares Nacionais: Ensino Médio. Brasília: MEC, 2000.

BRASIL. Ministério da Educação, Secretaria de Educação Básica, Ciências da natureza, matemática e suas tecnologias. Orientações curriculares para o Ensino Médio. v. 2. Brasília: MEC, 2006.

CACHAPUZ, A.; PRAIA, J.; JORGE, M. Da educação em ciência às orientações para o ensino das ciências: um repensar epistemológico. Ciência e Educação, v. 10, n. 3, p. 363-381, 2004.

CARVALHO, A. M. de. C. Prefácio. In: CACHAPUZ, A.; PRAIA, J.; GIL-PÉREZ, D.; CARVALHO, A. M. de. C.; VILCHES, A. (Org.). A necessária renovação do ensino das ciências. São Paulo: Cortez, p. 9-13, 2005.

CERQUEIRA, A. V. Representações sociais de dois grupos de professores de biologia sobre o ensino de Origem da Vida e Evolução Biológica: aspirações, ambiguidades e demandas profissionais. 2009. Dissertação (Mestrado em Educação em Ciências e Saúde), Núcleo de Tecnologia Educacional para a Saúde, Universidade Federal do Rio de Janeiro, UFRJ, Rio de Janeiro, 2009. biológica. Ciência e Educação, v. 17, n. 1, p. 115-128, 2001. 
DELIZOICOV, D.; ANGOTTI, J. A.; PERNAMBUCO, M. M. C. A. Ensino de ciências: fundamentos e métodos. São Paulo: Cortez, 2002.

EIDT, N. M.; TULESKI, S. C. Transtorno de déficit de atenção/hiperatividade e psicologia Histórico-Cultural. Cadernos de Pesquisa, v. 40, n. 139, p. 121-146, 2010.

FUTUYMA, D. J. Biologia evolutiva. 2. ed. Ribeirão Preto: Sociedade Brasileira de Genética, 1992. 830p.

GARRIDO, E. Sala de aula: espaço de construção do conhecimento para o aluno e de pesquisa e desenvolvimento profissional para o professor. In: CASTRO, A. D. de; CARVALHO, A. M. P. de. (Org.). Ensinar a ensinar: didática para a escola fundamental e média. São Paulo: Pioneira Thomson Learning, p. 125-141, 2001.

GÓES, M. C. R. de. A abordagem microgenética da matriz histórico-cultural: uma perspectiva para o estudo da constituição da subjetividade. Cadernos Cedes. Ano $X X$, n. 50, p. 9-25, 2000a.

GÓES, M. C. R. de. A formação do indivíduo nas relações sociais: contribuições teóricas de Lev Vigotski e Pierre Janet. Educação e Sociedade. Ano XXI, n. 71, p. 116-131, 2000b.

GRIMES, C.; SCHROEDER, E. A origem da vida, sob a ótica de licenciandos de um curso de Ciências Biológicas. Revista Electrónica de Enseñanza de las Ciencias, v. 12, n. 1, p. 126-143, 2013.

NICOLINI, L. B. Origem da Vida: como os licenciandos em Ciências Biológicas lidam com este tema? 2006. Dissertação (Mestrado em Tecnologia Educacional nas Ciências da Saúde), Núcleo de Tecnologia Educacional para a Saúde, Universidade Federal do Rio de Janeiro, UFRJ, Rio de Janeiro, 2006.

OLIVEIRA, M. K. de. Vygotsky: aprendizado e desenvolvimento - um processo sócio-histórico. 4 ed. São Paulo: Scipione, 2002.

PINO SIRGADO, A. O social e o cultural na obra de Vigotski. Educação e Sociedade, v. 21, n. 71, p. 45-78, 2000.

PORTO, P. R. de. A; FALCÃO, E. B. M. Teorias da origem e evolução da vida: dilemas e desafios no ensino médio. Revista Ensaio, v. 12 , n. 3, p.13-30, 2010. 
PRAIA, J.; CACHAPUZ, A.; GIL-PÉREZ, D. Problema, teoria e observação em ciência: para uma reorientação epistemológica da educação em ciência. In: PRAIA, J.; CACHAPUZ, A.; GIL-PEREZ, D.; CARVALHO, A. M. P. de.; VILCHES, A. (Org.). A necessária renovação do ensino das ciências. São Paulo: Cortez, 2005.

REGO, T. C. Vygotsky: uma perspectiva histórico-cultural da educação. 9. ed. Petrópolis: Vozes, 2000.

SANTA CATARINA. Secretaria de Estado da Educação. Proposta Curricular de Santa Catarina. Florianópolis: SED, 1998.

SANTA CATARINA. Secretaria de Estado da Educação, Ciência e Tecnologia. Proposta Curricular de Santa Catarina: Estudos Temáticos. Florianópolis: IOESC, 2005.

SANTOS, A. G. dos. Conhecimento científico, crenças religiosas e a compreensão dos fenômenos da natureza no ensino médio. 2007. Dissertação (Mestrado em Tecnologia Educacional nas Ciências da Saúde), Núcleo de Tecnologia Educacional para a Saúde, Universidade Federal do Rio de Janeiro, UFRJ, Rio de Janeiro, 2007.

SCHROEDER, E. A teoria histórico-cultural do desenvolvimento como referencial para análise de um processo de ensino: a construção dos conceitos científicos em aulas de ciências no estudo de sexualidade humana. 2008. Tese (Doutorado em Educação Científica e Tecnológica), Universidade Federal de Santa Catarina, UFSC, Florianópolis, 2008.

SILVA, S. M. C. da.; ALMEIDA, C. M. de. C.; FERREIRA, S. Apropriação cultural e mediação pedagógica: contribuições de Vigotski na discussão do tema. Psicologia em Estudo, Maringá, v. 16, n. 2, p. 219-228, 2011.

VYGOTSKY, L. S. A formação social da mente: o desenvolvimento dos processos psicológicos superiores. 6. ed. São Paulo: Martins Fontes, 1998.

VYGOTSKY, L. S. A construção do pensamento e da linguagem. São Paulo: Martins Fontes, 2001.

VYGOTSKY, L. S. Psicologia Pedagógica. 2. Ed. São Paulo: Martins Fontes, 2004.

VYGOTSKY, L. S. A defectologia e o estudo do desenvolvimento e da educação da criança anormal. Educação e Pesquisa, São Paulo, v. 37, n. 4, p. 861-870, 2011. 
WERTSCH, J. V. A necessidade da ação na pesquisa sociocultural. In: WERTSCH, J. V.; DEL RIO, P.; ALVAREZ, A. Estudos socioculturais da mente. Porto Alegre:

Artmed, p. 56-71, 1998.

ZANON, D. A. V.; FREITAS, D. de. A aula de ciências nas séries iniciais do ensino fundamental: ações que favorecem a sua aprendizagem. Ciências e Cognição, v. 10, p. 93-103, 2007.

Recebido: 2017-01-15

Aprovado: 2017-04-23

DOI: 10.3895/rbect.v10n3.5311

Como citar:

GRIMES, C.: SCHROEDER, E.. Contextos interativos no estudo do tema "Origem da Vida" em uma escola

pública, no Ensino Médio: compreensões de um professor de Biologia. Revista Brasileira de Ensino de

Ciência e Tecnologia, v. 10, n. 3, 2017. Disponível em: <https://revistas.utfpr.edu.br/rbect/article/view/5311>

Acesso em: xxx.

Correspondência:

Camila Grimes- professora.camilagrimes@gmail.com

Direito autoral: Este artigo está licenciado sob os termos da Licença Creative Commons-Atribuição 4.0

Internacional.

c) (i) 